\title{
Supporting Agricultural Ecosystem Services through the Integration of Perennial Polycultures into Crop Rotations
}

\author{
Peter Weißhuhn ${ }^{1, *}$ (D), Moritz Reckling ${ }^{1}$ (D), Ulrich Stachow ${ }^{1}$ and Hubert Wiggering ${ }^{2}$ \\ 1 Institute of Land Use Systems, Leibniz Centre for Agricultural Landscape Research, Eberswalder Straße 84, \\ D-15374 Müncheberg, Germany; moritz.reckling@zalf.de (M.R.); stachow@zalf.de (U.S.) \\ 2 Institute of Earth and Environmental Science, University of Potsdam, Karl-Liebknecht-Straße 24/25, \\ D-14476 Potsdam, Germany; wiggerin@uni-potsdam.de \\ * Correspondence: weisshuhn@zalf.de; Tel.: +49-33432-82-271
}

Received: 1 November 2017; Accepted: 5 December 2017; Published: 7 December 2017

\begin{abstract}
This review analyzes the potential role and long-term effects of field perennial polycultures (mixtures) in agricultural systems, with the aim of reducing the trade-offs between provisioning and regulating ecosystem services. First, crop rotations are identified as a suitable tool for the assessment of the long-term effects of perennial polycultures on ecosystem services, which are not visible at the single-crop level. Second, the ability of perennial polycultures to support ecosystem services when used in crop rotations is quantified through eight agricultural ecosystem services. Legume-grass mixtures and wildflower mixtures are used as examples of perennial polycultures, and compared with silage maize as a typical crop for biomass production. Perennial polycultures enhance soil fertility, soil protection, climate regulation, pollination, pest and weed control, and landscape aesthetics compared with maize. They also score lower for biomass production compared with maize, which confirms the trade-off between provisioning and regulating ecosystem services. However, the additional positive factors provided by perennial polycultures, such as reduced costs for mineral fertilizer, pesticides, and soil tillage, and a significant preceding crop effect that increases the yields of subsequent crops, should be taken into account. However, a full assessment of agricultural ecosystem services requires a more holistic analysis that is beyond the capabilities of current frameworks.
\end{abstract}

Keywords: agroecosystem; assessment; legume-grass mixture; wildflower mixture; perennial crop; mixed cropping

\section{Introduction}

Many agricultural systems worldwide have been developed to productive high-input and specialized cropping systems with limited options for versatile rotations, perennials, and polycultures (mixed crops). This development led to negative environmental impacts and affected a wide range of benefits obtained from the agroecosystem [1]. In contrast to high-input agriculture, agroecology evolved as a science and a movement [2], providing alternative farming strategies such as emphasizing rotations, legumes, cover cropping, etc. Through a more efficient use of resources, a partial substitution of crops in a rotation, or a total redesign of the cropping system [3], agroecology provides opportunities for the integration of perennial polycultures. The strategy of sustainable intensification has been developed to simultaneously reach or maintain high levels of production and reduce negative environmental impacts and biodiversity loss [4-8]. This strategy also gives opportunities for the use of perennial polycultures through enhancing internal agroecosystem regulation processes [9] while reducing external human regulation such as intensive fertilization or soil tillage. 
In contrast to annual or biennial plants, perennial plants grow for several years, are typically harvested annually or cut several times per year, and are removed after two to five years. In current agriculture, perennial grasses and legumes for forage (e.g., Glover et al. [10], Asbjornsen et al. [11]) and some perennial energy crops (e.g., Franzluebbers [12], Mast et al. [13]), are used, while perennial grains for food are under development (e.g., Reganold [14], Zhang et al. [15]). Perennial polycultures combine a multispecies approach with perenniality. For agriculture, polycultures can be defined as the growing of two or more crops together simultaneously on the same piece of land [16,17]. Terms with similar meaning include mixed cultures, crop mixtures, and intercropping.

To identify and assess benefits from natural systems, the concept of ecosystem services (ES) was developed and is frequently used. In agricultural ecosystems, ES contributions to human well-being depend on inputs such as seed, fertilizer, and labor/machinery [18,19]. Agricultural ecosystems are key providers of several ES [20]: (i) the provision of food, feed, fiber, biogenic chemical matter, and fuel; (ii) the regulation of pollen transfer and agricultural pests; and (iii) recreation, education, cultural heritage, and sense of place. The traditional aims of agriculture can be described as maximizing the provisioning ES, while at the same time, agriculture depends on a range of other ES, including regulating services and services that support provisioning [21]. In particular, agriculture benefits from the suppression of pests [22,23], pollination [24,25], water availability in appropriate quantity and quality [26,27], and the maintenance of soil fertility and a favorable soil structure [28].

To achieve the intended provisioning of ES, agricultural management typically applies several strategies, and crop rotations are one of the most important strategies [29-31]. Crop rotations are the sequence of different crops grown on a specific field, often in a generally fixed cycle over several years [32]. Crop rotation is considered the starting point for the analysis of cropping systems [33], and supports the evaluation of long-term effects of the cropping system on ecosystem services that are not visible at the single-crop level [30]. We argue that there is a large potential for enhancing ES in several agricultural systems through the integration of perennial polycultures (e.g., Cattani [34], Oates et al. [35]) in crop rotations. A good example for livestock farming systems are legume-grass mixtures grown for forage to save inputs and yield synergies between productivity and biodiversity [36-38]. Farms that grow crops to produce biogas can grow novel crops such as wildflower mixtures with potential benefits regarding low production costs, high yields, and the support of biodiversity $[39,40]$. This review investigated the additional ES that perennial polycultures provide, and how their integration could increase the sustainability of agricultural land use.

Comprehensive assessment protocols are needed for effective management strategies, including trade-off analyses [41-43]. Although there is no standard set of ES from agricultural ecosystems, this review suggests principles to derive a comprehensive and efficient set using the example of perennial polyculture cropping systems.

This work aims to review the effects of perennial polycultures on agricultural ES. First, the concept of crop rotation is introduced as a means for a multi-year perspective on ES assessment, and crop rotation principles are translated to particular ES. Second, a comparative assessment of legume-grass mixtures and wildflower mixtures was performed to exemplify the effects of introducing perennial polycultures on ES. Third, reflections are added on the appropriateness of the ES assessment procedure, the limitations of perennials and polycultural cropping, and the potentials of perennial polycultures for nature conservation.

\section{Crop Rotation and Perennial Polycultures}

\subsection{Crop Rotation and Ecosystem Services}

The choice of appropriate crop rotations is the main agroecosystem management strategy to secure agricultural production by maintaining soil fertility, suppressing harmful organisms (weeds, diseases, pests) [29], and increasing the overall resilience of agricultural systems [44,45]. A recent analysis of European crop rotations, however, revealed that the most practiced crop rotations in arable 
farms are on average three to four years long, and focus on market crops. Cereals often dominate, with a proportion of $75 \%$ or more [46], while legumes, which are well known for multiple beneficial rotational effects, are rare [47]. This shows that the use of agricultural inputs such as pesticides and fertilizers, nowadays substitute several of the rotational benefits [3], and consequently lead to more narrow crop sequences [48]. Rotations might gain a greater appreciation again due to plant protection issues such as weeds, animal pests, pathogens, and viruses [49], especially considering the rapid development of pesticide-resistant populations globally (e.g., Nicholson [50], Whalon [51]) as crop rotations may be the principle method to suppress these harmful species [52].

Some aims of crop rotations refer to the farm organization, e.g., the temporal spread of the workload and machine usage for growing different crops. Other important considerations such as the avoidance of risks add to the complexity of deciding upon the optimal crop rotation [29]. The main aims and constraints of crop rotations can be summarized as "crop rotation principles" [30]. To our knowledge, agricultural ES in relation to the corresponding crop rotations have not been studied. Therefore, a conceptual translation of generalized crop rotation principles to ES seems beneficial (Table 1). Various ES are targeted by crop rotations, especially provisioning and regulating ES. However, cultural ES are not a focus. In some cases, crop rotation principles are not directly linked to an ES as defined above, and therefore, an intermediate translation step is helpful. For this intermediate step, we suggest referring to an underlying ecosystem process or function [53]. The Millennium Ecosystem Assessment [54] classified such processes or functions, for example, nutrient cycling-which includes fixation, storage, transformation, and release-as supporting services, which should be considered an ecosystem function rather than an ES [55], and have been recently excluded from ES classifications (e.g., [56]). For example, one goal of crop rotation is maintaining soil organic matter (SOM), which is closely related to the ecosystem function carbon cycling and thus further to the ES of soil protection, climate regulation (carbon sequestration), and biomass production.

Table 1. Translation of crop rotation principles to ecosystem functions and ecosystem services. SOM: soil organic matter.

\begin{tabular}{|c|c|c|}
\hline General Crop Rotation Principle & Ecosystem Function & Ecosystem Service \\
\hline Integration of legumes & nitrogen cycling & $\begin{array}{l}\text { regulating: Soil fertility } \\
\text { provisioning: Biomass production }\end{array}$ \\
\hline $\begin{array}{l}\text { Alternation of SOM-decreasing and } \\
\text { SOM-increasing crops }\end{array}$ & $\begin{array}{l}\text { carbon cycling, plant } \\
\text { hydrologic balance }\end{array}$ & $\begin{array}{l}\text { regulating: Soil protection, climate } \\
\text { regulation } \\
\text { provisioning: Biomass production }\end{array}$ \\
\hline Integration of intercrops and cover crops & carbon cycling, nitrogen cycling & $\begin{array}{l}\text { regulating: Soil protection, soil fertility } \\
\text { provisioning: Biomass production }\end{array}$ \\
\hline $\begin{array}{l}\text { Keeping specific frequency limits for each } \\
\text { crop and crop type }\end{array}$ & $\begin{array}{l}\text { (limiting) habitats for pests, } \\
\text { diseases and weeds }\end{array}$ & regulating: Pest control, weed control \\
\hline
\end{tabular}

\subsection{Examples of Perennial Polycultures}

Although a few examples of combining the principles of polyculture and perenniality are well known, i.e., legume-grass mixtures, such combinations are still seen as an innovative approach in current farming systems, and experiences are limited as a result. Our analysis looks at perennial polycultures suitable for integration in crop rotations on arable fields. Here, we focused on 
legume-grass mixtures and wildflower mixtures as examples for the contribution of perennial polycultures to ES in agricultural systems.

Legume-grass mixtures for forage often contain red clover (Trifolium pratense), alfalfa (Medicago sativa), and different grass species adapted to regional conditions (e.g., Braun et al. [57], Biewer et al. [58], McElroy et al. [59], Sleugh et al. [60]). The species combination can be adjusted for different environmental conditions and aims, such as aboveground biomass, feed quality, and preceding crop effect (belowground biomass, nitrogen or carbon balance) by varying the shares of grasses and legumes [61]. Legume-grass mixtures are of importance for large parts of Europe [38], while the legume species used and the mixtures differ between temperate and Mediterranean areas [62].

From the context of energy crops, which have increased significantly within the last decades e.g., in Germany [63], wildflower mixtures comprise a set of core species accompanied by a variety of additional plant species that are adapted to local conditions and developed for its use purposes. Wildflower mixtures of approximately 25 species [40] harmonize plants with complementary life cycles, e.g., annuals, biennials, and perennials over an entire cultivation period of up to five years. So far, results from field trials with wildflower mixtures have been reported for sites in Germany only, but the potential growing region may exceed Central Europe.

\section{Methods}

\subsection{Literature Search}

Our qualitative analysis of ES provided by the integration of perennial polycultures in crop rotation is based on published results. As the topic of perennials and polycultures has been rarely considered in connection with ES, a search query was applied with few restrictions (all years, databases, and document types) for titles that included the term "ecosystem service*" in connection with the term "intercrop" "crop" ${ }^{* \prime}$ or "agricult" in a range of three words. The searches on Web of Science (WoS) and Scopus revealed almost the same results, and returned only 14 useful papers. Therefore, Scopus was employed to extend the search to the abstracts. Of the returned 126 entries (including those 14 useful articles), 50 articles were derived that concerned perennial crops or crop mixtures on arable land. The other articles were out of scope, because they focused on permanent grassland, agroforestry, orchards, or vineyards.

As the review focused on ES derived from the integration of legume-grass mixtures and wildflower mixtures, a WoS search was employed for topics with the term "ecosystem service*" in connection with "legume" and "grass" or in connection with "wildflower", while excluding the terms "agroforestry", "prairie", "permanent grassland", "wildflower strips", "blueberry", and "blackberry". The query returned 49 entries, $\mathbf{1 5}$ of which were relevant.

The 75 useful articles provided sufficient evidence for most of the investigated ES (see Section 4) regarding legume-grass mixtures, although in some cases, additional specific literature was considered. Regarding wildflower mixtures, only the pollination service was repeatedly mentioned. Thus, we extended our literature search to publicly available reports and documents to incorporate relevant knowledge sources. The analysis of wildflower mixtures mainly relies on project results from several locations in Germany (Lower Saxony, Brandenburg, Bavaria, and Baden-Württemberg, as reported by Vollrath and Werner [64], Vollrath et al. [65], and von Cossel and Lewandowski [40], respectively).

\subsection{Definition of Ecosystem Services}

A comprehensive set of ES aims to avoid excluding relevant aspects of ecosystem management. Particularly, agricultural ES are only provided in combination with human input [18]. Agriculture manipulates and utilizes the ecosystem to produce commodity outputs (i.e., the harvest), which are intertwined with non-commodity outputs-whether positive or negative externalities-such as the preservation of cultural landscapes or environmental pollution [66]. Both types of output should be reflected in a comprehensive set of ES with a manageable number of ES. The ES assessment includes 
ES on the farm level and on higher levels, e.g., on a landscape scale. The distinction of ES avoids double-counting due to overlap, though interrelations between the different ES are very likely.

To adapt the ES concept to agricultural ecosystems, general ES literature was selected (e.g., MEA [54], Costanza et al. [67], de Groot et al. [68]), as well as ES studies with an agricultural context [21,69-72]. As trade-off analyses between multiple ES were of special interest, the concept of 'ES bundles' may also seem promising, as it combines sets of services that appear together repeatedly and have close interactions [73,74]. However, this review did not structure the investigated ES in bundles, as they are very case-specific, and socio-economic background influences the aggregation of ES.

After considering this background and the need to maintain a manageable sample number, eight ES were derived to provide a comprehensive overview, covering, inter alia, the ES derived from the crop rotation principles (cf. Table 1). They include biomass as the aggregated key provisioning ES from agroecosystems, and several central regulating services, which cover the core environmental spheres: soil (the pedosphere), water (the hydrosphere), climate (the atmosphere), and biodiversity (the biosphere). Landscape aesthetics may stand in for the cultural ES as it is the most commonly investigated and least-formalized issue in the scope of the ES concepts [75]. The identified eight ES are described in the following Sections 4.1-4.8, which analyze the literature on the two examples of perennial polycultures.

\section{Review of Ecosystem Services Provided by Perennial Polycultures}

\subsection{Soil Fertility}

Soil fertility is one of the most fundamental ES considering agricultural benefits, and has a primarily indirect value. Soil fertility is composed of many underlying ecosystem processes and structures. Important indicators for soil fertility are SOM content and the ratio of carbon (C) and nitrogen $(\mathrm{N})$. The natural supply of SOM predominantly results from the roots and stubble residues [48]. Temporary agricultural grasslands are known to increase soil fertility over time and result in an economical preceding crop effect (greater yield from successive crops). Even short-term ( $<3$ years) grasslands in a crop rotation can provide benefits to soil quality [76].

The empirical data from legume-grass mixtures optimized for carbon sequestration on fertile soils show quantities of fixed carbon during the first year of $10.8 \mathrm{t} \mathrm{C} /$ ha during the mulch process, and $3.6 \mathrm{t} \mathrm{C}$ /ha with cutting. After SOM formation, this corresponds to $2.4 \mathrm{t} \mathrm{C} /$ ha and $1 \mathrm{t} \mathrm{C} / \mathrm{ha}$, respectively [61]. These results consider the roots at the time of harvesting, but only account for $30-50 \%$ of roots during vegetation, so the fixed carbon should be even higher. Standard values for soil carbon balances of silage maize cropping estimate losses from $0.56 \mathrm{tC} /$ ha to $1.04 \mathrm{tC} / \mathrm{ha}$, compared with a soil carbon supply from legume-grass mixture cropping between $0.6 \mathrm{t} \mathrm{C/ha}$ and $0.8 \mathrm{tC} / \mathrm{ha}$ [77]. A very high proportion of grasses in the mixture exhibits a high carbon capture rate, but results in a poor trade-off with the nitrogen balance, whereas a mixture with a high proportion of legumes in the seed $(\geq 80 \%)$ exhibits high carbon capture rates and fixes more nitrogen, up to $540 \mathrm{~kg} \mathrm{~N} /$ ha per year [61]. The $\mathrm{N}$ accumulation from the grass component of the mixture is also important for the soil fertility increase, and appears to be influenced more by the grass $\mathrm{N}$ demand than the legume $\mathrm{N}$ supply [59]. The effects of perennial legume cultivation on the subsequent crops are apparent until the third and fourth year $[48,78]$. Forage legumes have a high preceding crop effect due to the large amounts of roots and residues left after harvesting [79].

In theory, the effects of cropping wildflower mixtures are favorable in two ways. First, the suspension of soil tillage for up to five years enables undisturbed development of soil biota. Second, the nutrient availability benefits from the increased supply of carbon after intensive perennial root development and, in the case of legume-based mixtures, from the supply of nitrogen [64]. However, there was no increase in SOM found after growing wildflower mixtures [65]. 


\subsection{Biomass Production}

Usable biomass includes all of the products from arable plants, such as the seed, fruit, leaf, straw, and tuber that supply food, feed, fiber, and fuel. Typically, crop mixtures produce more biomass as species richness increases [80], but the biomass is lower than high-yielding monocultures [81]. In general, for forage and biofuel production, both the yield quantity and quality are important; as such, they are both considered for the analysis.

With repeated cutting of legume-grass mixtures, nearly as much dry matter can be obtained as silage maize cropping. For example, on sandy soils and in a dry temperate climate in Brandenburg, legume-grasses are estimated to yield $9.1 \mathrm{t} /$ ha compared with $9.4 \mathrm{t} /$ ha from silage maize [47]. On more fertile soils, legume-grass mixtures yield approximately $16.5 \mathrm{t} / \mathrm{ha}$ [61]. Instead of the common dry matter, other studies quantify the fresh matter yield from approximately $20 \mathrm{t} / \mathrm{ha}$ for soils with medium soil fertility to approximately $60 \mathrm{t} / \mathrm{ha}$ for soils with higher fertility [82]. The main value of the yield is for animal feeding, as the protein content of alfalfa and clover grasses is very high. For example, dairy cattle obtain $60-70 \%$ of their protein requirement from such roughage [83], and it supports a healthy digestion. The lower production of milk and meat from ruminants are not expected if soya meal is substituted with protein from forage legumes $[79,84]$, and soya imports can be reduced. In energy crop cultivation, legume-grass mixtures have proven to be a marketable intermediate crop for best-yielding crop rotation at a cool and moist calcareous brown soil location. However, the costs of multiple cutting each year have a negative impact if it is a perennial main crop [85].

Wildflower mixtures optimized for biogas production must compete with the currently economically favored silage maize cultivation that has an average annual dry matter yield of $16 \mathrm{t} / \mathrm{ha}$ [64]. For wildflower mixtures, mean dry matter yields of approximately $9 \mathrm{t} / \mathrm{ha}$ [64] and $12 \mathrm{t} / \mathrm{ha}[40,86]$ were reported. Zürcher et al. [87] reported wildflower mixture yields from $8 \mathrm{t} / \mathrm{ha}$ to $14 \mathrm{t} / \mathrm{ha}$, which is approximately $50 \%$ of the yield of silage maize under the same conditions. However, there is potential for improvement, because some weak species in the mixture lower the average yield. The mean yield of the first crop year of wildflower mixtures by annual plant species is predominantly between $4 \mathrm{t} /$ ha and $9 \mathrm{t} / \mathrm{ha}$, but can reach $22 \mathrm{t} / \mathrm{ha}$ in good locations. Eight to $15 \mathrm{t} / \mathrm{ha}$ can be realized in the second year by the biennial plant species, and up to $17 \mathrm{t} / \mathrm{ha}$ from the third year on with native perennials [64]. For biogas production, the methane yield is of importance, and is compared using the specific methane yield of crops. The produced methane per $\mathrm{kg}$ of dried biomass of wildflower mixture harvest amounts to approximately 250 standard liters compared with approximately 360 standard liters for silage maize [87]. Vollrath et al. [39] reported higher yields for their wildflower mixtures of 270-320 standard liters, translating to a 15\% lower specific methane yield than silage maize. Slight increases in yield quality (better specific methane yield) are possible through earlier cutting, at the expense of yield quantity (biomass yield). Through the use of several complementary-yielding plant species, a higher yield stability was reached. If one main yielding species fails, for example due to dry spring conditions, other species grow stronger and compensate for the otherwise occurring yield loss [64].

\subsection{Soil Protection}

For this review of agricultural ES, soil protection was determined by the vulnerability of a soil to compaction, contamination, and erosion. As the soil compaction sensitivity is essentially determined by the soil moisture content [88], conditions for rapid drying are beneficial. Erosion can primarily be controlled by a protecting vegetation cover, which protects the soil from silting that disturbs infiltration capability and reduces the sediment transport capacity of the runoff. Further, the soil is stabilized at the aggregate level by a high proportion of organic material in the soil particles, and at the field level by intensive rooting [89].

Legume-grass mixtures provide increased resistance against soil erosion and soil compaction through a permanent ground cover, improved aggregate structure, high porosity and higher water demand from the culture [48]. The intensive root development works against existing soil compaction; 
for example, the deep rooting alfalfa can break up compacted soil layers. The outreach of the roots and root mass of legume-grass mixtures increases with the proportion of legumes, while the overall root length increases with the proportion of grasses [61]. The reduced need for fertilizers and pesticides also reduces the exposure to contaminants.

Wildflower mixtures also aid the rapid drying of the soil through supporting soil porosity and high water demands. A fully soil-covering vegetation layer will be established approximately four weeks after sowing, thus reducing erosion almost year-round [64]. The intensive rooting of perennial plants further stabilizes the soil structure. The severely reduced necessity for fertilization, pesticides, and the associated machinery traffic on the fields considerably reduces the exposure to soil compaction and contamination [65].

\subsection{Water Availability}

The ES related to water are manifold, because they include aspects of water quantity and quality. As contamination is already covered (see Section 4.3), this section is focused on the influence of perennial polycultures on the water balance, not on water quality. Water storage and discharge capacity are mainly governed by soil and climate variables and, to a limited extent, by the crop. The draining capacity benefits are closely bound to erosion control, and are primarily related to soil infiltration characteristics (see Section 4.3). Water availability benefits in this analysis relate to influences on the amount of plant-available water rather than drinking water resources, although the ground water recharging rate is influenced by the crop [90]. In general, annual crops favor water infiltration, but not maize [91].

Deep rooting species of legume-grass mixtures, such as alfalfa, can take up water and nutrients from deep soil layers, and are well adapted to dry conditions. However, this high consumption of soil water could be limiting for the subsequent crop [48].

Wildflower mixtures usually benefit from a high availability of water, but could be adapted to local conditions [64]. No reliable statements were found regarding its effects on soil water.

\subsection{Climate Regulation}

The impact of agricultural systems on drivers of climate change is typically expressed in terms of greenhouse gasses, SOM, and carbon balances. The quantitative findings regarding the carbon balances and SOM are frequently assigned to soil fertility, but can also be used as an indication of the sink function regarding atmospheric greenhouse gases. Another role of cropping in climate protection involves determining the amount of emissions from the use of fossil fuels to produce the machinery and fertilizer, and to run the machines. Further, emissions from the microbial decomposition of fertilizers and other agricultural chemicals have to be considered.

Legume-grass mixtures are beneficial compared with agricultural grasslands with the same yield. Clover grass undergoing a three-year cultivation exhibits average annual emissions of $2.4 \mathrm{~kg}$ nitrous oxide $\left(\mathrm{N}_{2} \mathrm{O}\right)$ per hectare compared with approximately $9.9 \mathrm{~kg} \mathrm{~N} \mathrm{~N}_{2} \mathrm{O}$ per hectare for agricultural grassland fertilized with $360 \mathrm{~kg} \mathrm{~N} / \mathrm{ha}$ [92]. In general, compared with annual corn monocultures, perennial grass-legume mixtures show significantly lower $\mathrm{N}_{2} \mathrm{O}$ emissions [93]. Savings made on the technical fertilization quantities through the symbiotic $\mathrm{N}_{2}$ fixation will result in an improved climate balance for the crop rotations, initially indirectly through the reduced use of fossil energy, and later through fewer nitrous oxide emissions from the fields, which amounts to $8.35 \mathrm{~kg} \mathrm{~N}_{2} \mathrm{O} /$ ha for silage maize cropping compared with $1.54 \mathrm{~kg} \mathrm{~N}_{2} \mathrm{O}$ /ha for clover grass (as reported by Reckling et al. [47], which is calculated using IPCC Tier1 methodology). Furthermore, perennial mixed grasses are reported to facilitate microbial methane consumption at an order of magnitude higher than that of maize, and therefore contribute to greenhouse gas reduction [94]. The favorable soil structure under legume-grass mixtures leads to easier tillage and fuel savings. Notably, the workload is relatively low, and expensive peak-working periods can be broken up to reduce energy and machinery input. 
A five-year cultivation of wildflower mixtures builds up significant belowground biomass, which boosts the sink function regarding atmospheric carbon. Furthermore, due to a low level of intervention, with approximately half of the working steps and operating resources of silage maize [65], growing wildflower mixtures showed reduced greenhouse gas emissions at several stages of the production chain.

\subsection{Pollination}

The pollination service is dependent on vital pollinator communities, which are threatened in intensively used agricultural landscapes $[95,96]$. They need floral resources throughout the growing season to forage, and nesting resources as well $[97,98]$. Additionally, the distance to the benefitting crops [99] and the specific pollination dependence of these crops [24] must be considered to estimate the actual service provision level.

Legume-grass mixtures contain alfalfa and red clover as nectar-bearing crops. Although alfalfa is inefficiently pollinated by honeybees (Apis mellifera), it supports many wild pollinators [100]. However, if cutting is conducted frequently, the flowering aspect is usually suppressed, and an adapted harvest regime and appropriate species mixture are necessary to provide floral resources [101].

Honeybee colonies benefit from the richer availability of pollen and nectar in wildflower mixtures [65], and the diversity and density of hoverflies and wild bees also increase in relation to the size of the flowering plant area [102]. Depending on the particular spectrum of species, wildflowers allow for pollinator foraging until the beginning of autumn, and thereby increase the survival of honeybee colonies over the winter [64].

\subsection{Pest and Weed Control}

Keeping agricultural pest populations at bay can primarily be facilitated by appropriate crop rotations and reinforcing natural enemies. Regarding different crop types, the greatest biocontrol services are expected from perennial crops [103,104]. Variable flowering aspects throughout the vegetation period and differences in plant architecture indicate higher insect biodiversity [105], including potential natural enemies. This is related to crop rotation principles for limiting habitat opportunities for pests, diseases, and weeds (see Table 1), and is also related to the function of a break crop [106,107].

Legume-grass mixtures can interrupt pest development cycles if placed in a suitable crop rotation position. The control of aphids, for example, by natural enemies is most promising in grass and herb crops, and is less suited for legume crops [108]. Perennial legume-grass mixtures strongly decrease the risk of annual summer weeds and also reduce annual winter weeds, especially if grown for three years [109]. The dense vegetation structure and the repeated cutting weaken the vegetative organs of the competing weed plants [48], decreasing the broadleaf (and not grass) weed seed bank and increasing weed diversity [110].

Wildflower mixtures support pollinator species and many other flower-visiting species such as parasitic wasps, predatory hoverflies, and pollen beetles, which potentially provide pest control [111]. Organizing the harvest outside the breeding and rearing times supports birds and other potentially beneficial organisms [64]. The weed control is precarious during the establishment of the seeds. If well established, wildflower mixtures normally exhibits high above and belowground stock density, which suppresses weeds [65].

\subsection{Landscape Aesthetics}

In general, the scarcity value and diversification effect of a field crop depend on its proportion in the local context and its regional or even global conservation value. This refers to landscape complexity as an explanatory factor for landscape preference [112]. Landscape perception and rating is strongly positively influenced by flowering stages and the perceived diversity and naturalness of landscape elements [113]. 
Legume-grass mixtures contribute to a pasture-like character of the landscape, especially in simple rotations of annual cash crops or landscapes where the grassland area is declining. No reports on the perceived naturalness or beauty were found, although it is obvious that legumes may bloom spectacularly.

Wildflower mixture can grow up to two meters high, and is, compared with silage maize, much more versatile during the vegetation period, as the dominating species are changing. Furthermore, different blooming aspects are visible, and will have a positive effect on the natural scenery several times a year [64].

\section{Qualitative Comparison of Alternative Systems}

The eight agricultural ES were reviewed regarding legume-grass mixtures for forage and wildflower mixtures for biogas production. Their level of ES provision, which is overviewed in (Table 2), was compared with silage maize as a common crop for forage and biogas production. Therefore, the ES provision level scores have a relative meaning that refers to an agricultural ecosystem under maize cropping and should be understood as a qualitative synthesis of Sections 4.1-4.8. The included study results did not always show a direct link to the ES we paired them with, although their results nevertheless contribute to explanations of the ES provision level. For details on the scoring and references, see the respective ES section. Since all ES differ and may be valued differently by the beneficiaries, a drawback in one ES cannot be simply counterbalanced by a benefit from another ES.

Table 2. Qualitative scoring of the provision level of each ecosystem service for two perennial polycultures investigated by literature review in comparison with maize cropping.

\begin{tabular}{ccc}
\hline Ecosystem Service & Legume-Grass Mixture $^{\mathbf{a}}$ & Wildflower Mixture $^{\mathbf{a}}$ \\
\hline Soil fertility & ++ & + \\
Biomass production & - & - \\
Soil protection & ++ & ++ \\
Water availability & + & $\mathrm{n} / \mathrm{a}$ \\
Climate regulation & ++ & ++ \\
Pollination & + & ++ \\
Pest and weed control & + & + \\
Landscape aesthetics & + & ++ \\
\hline
\end{tabular}

a Scoring: - lower, + higher, ++ clearly higher than silage maize, $n$ /a: No data available; based on study results presented in Section 4.

The two perennial polycultures scored very similarly, and had many positive impacts in relation to silage maize. No clear effects were identified for wildflower mixtures regarding the water availability. The poor scoring of both polycultures compared with silage maize in a single ES, i.e., biomass production, is noticeable. This trade-off has also been reported for perennial energy crops in North America [114].

\section{Perspectives}

\subsection{Potentials and Limitations of the Ecosystem Services Concept to Agricultural Ecosystems}

In comparison with other methods used for sustainability assessment, the ES concept can examine sustainability from a primarily ecological perspective [115]. The same is valid for our set of ES, which involved socio-economic aspects to a very limited extent, which were integrated in the one cultural ES of landscape aesthetics.

In order to analyze the economic aspects the ES, biomass production alone is not a sufficient indicator, although it is a main variable for agricultural management decisions. For example, the variable costs of wildflower mixtures are below $400 € /$ ha, which is half that of silage maize cultivation [86], and favors areas with low land prices (e.g., marginal sites). This translates to costs per ton of biomass that are 
lower than those of silage maize if land prices are excluded [64]. However, if the price of land is higher and ES are not considered, the increased land requirement for the perennial polycultures will result in lower profitability than that of silage maize cultivation. This could be balanced by an economic appreciation for ES, which could be implemented indirectly through restrictions in the greening of the European common agricultural policy or directly through payments for ES (e.g., [116]). Schläfke and Uckert [86] calculated a necessary subsidy of $164 € /$ ha in order for wildflower mixtures to be economically favorable in eastern Saxony (Germany). However, the monetization of ES does not allow for a comparison or offsetting between each of the ES.

An opportunity for the design of cropping systems with optimal ecological performance lies in structured ES trade-off analyses [117]. Any proposed set of ES might be difficult to compare with other ES studies. For future comprehensive applications of the ES concept to agricultural ecosystems, a more strict orientation to established frameworks, e.g., The Common International Classification of Ecosystem Services (CICES, e.g., Haines-Young and Potschin [56]) could help to harmonize results. Other attempts such as the mapping approaches conducted by Burkhard et al. [118,119], methodological standardization [120], or efforts towards a common national classification system in Germany [121] could also be considered.

The ES assessment in this review is based on generalized knowledge from case studies and scientific literature to identify the effects of different cropping systems. Therefore, the qualitative results should be interpreted as a rough estimation. It gives orientation towards the potentials and limits for the provision of ES, but quantitative estimations would be more helpful for the adaptation of perennial polycultures in crop rotations. At this stage, the findings should be tested through applications to several different environments and farming systems that involve conceptual modeling, numerical modeling, and prototyping [117], followed by field trials. Agricultural locations are often heterogeneous, and require detailed field data to improve ES management [122].

Originally, the ES concept was conceived for natural or semi-natural ecosystems. However, agricultural ecosystems are profoundly transformed, and the energy and technology that are used in the agricultural production process are not well covered by the traditional ES framework. Excluding the anthropogenic inputs (e.g., labor, fertilizers, pesticides, etc.), the human benefit provided by the agroecosystem would be much lower [18]. To overcome these conceptual problems and address this anthropogenic factor in ES, an analysis of "agrosystem services" [19] or a complementary life cycle assessment could be useful. In addition to the positive effect on biomass production, the energy and technology use must be considered due to negative externalities such as $\mathrm{CO}_{2}$ emissions, the negative impact on soil fertility and biodiversity, soil compaction, and other environmental damages. The ES soil protection captures the potential of reducing negative externalities of agricultural production, while the protection of water bodies (from pollution) is missing, and should also be included in future comprehensive studies on agricultural ES.

\subsection{Potentials and Limitations of Perennial Polycultures}

Although perennials offer multiple options for arable farming production in many European crop rotations, its main benefit for forage production is restricted to mixed farms with crop and livestock production. Alternative uses for perennial forages could be employed through farm collaborations with livestock farmers and production for the delivery of green biomass to biogas plants [123], which is the main track for wildflower mixtures. Other agronomic constraints in perennial forage production include reduced operational flexibility, short-term market orientation, crop establishment, and the maintenance of a sufficient proportion of approximately one third of legumes in legume-grass mixtures [37]. This may partly explain why the area of permanent and temporary grassland in Europe is shrinking [124]. Still, higher crop yields in subsequent crops can justify lower economic returns from perennial forages in many cases, and lead to an overall positive economic and environmental result at the cropping system scale [47]. 
The central advantage of polycultural cropping is based on the complementary utilization of natural resources such as light, water, or nutrients, potentially resulting in higher biomass yields than crops grown individually $[125,126]$. This is defined by a land equivalent ratio (LER) greater than one, meaning that the yields of each species of the mixture grown in pure stands would require a larger area in total compared with the cultivation in mixture. Thus, polyculture has the potential to save land. Polycultures with LERs greater than one in European cereal-legume intercropping systems include pea with wheat, or barley and faba bean with wheat or barley [127-130]. Additionally, the use of polycultures was proposed to achieve synergies among ES from agricultural ecosystems [21] or to enhance ecosystem properties that are closely linked to ES [126]. Integrating polycultures into typical market-oriented, narrow crop sequences would contribute to a transition towards more sustainable systems by redesigning agricultural practices based on diversification [3]. For example, a cereal-grain legume polyculture could significantly improve yield stability compared with sole crop production [131]. Above the field scale, diverse cropping systems are less vulnerable to perturbations such as wide-spreading plant diseases, or stresses such as climate change, and thereby increase food security [132]. Still, in practice, the adoption rate of annual polycultures has remained relatively low [133], and it is difficult to select and devise the optimum cultivation design [134]. Sanford et al. [135] could not verify yield advantages of diversity for mixed perennial bioenergy cropping systems. Generally, compared with sole cropping, multispecies systems are potentially more difficult to manage, and require substantial farmer skills and specific research efforts [126]. A greater diversity of pests and diseases can occur in mixtures, and the sanitizing effects of monocultures would be lost [136]. Optimal planting times, and the provision of nutrients, weed control, and harvest activities are some of the serious challenges of polyculture management.

A promising strategy to increase the adoption of perennial polycultures could be a stepwise approach that first promotes perennials as sole crops, such as the perennial cultivation of alfalfa, and annual polycultures, such as intercropping wheat with pea. In a second step the cultivation of perennial polycultures could be encouraged. The adoption strategy may learn from ES trade-offs of polycultural farming systems based on long-living perennials such as grapevine, cocoa plantations, or other agroforestry systems [117]. Additionally, novel perennial crops such as cup plant (Silphium perfolatium), energy dock (Rumex schavnat), giant knotweed (Falopia sachalinensis var. igniscum), and Szarvasi (Elymus elongatus ssp. ponticus cv. Szarvasi-1) [13] have been adopted for biogas production. Regarding yield and ES, many promising perennial grains are under development $[14,15,137]$, and research on perennial staple crops is increasing [138]. Plant breeding efforts aim to integrate a perennial habit into many important annual crops, such as rice, wheat, rye, sorghum, soybean, and several oil crops [139].

\subsection{Potentials for Nature Conservation}

The integration of perennial polycultures in arable fields provides opportunities for environmental and wildlife-friendly land use, and therefore underpins the concept of land sharing in the debate on whether land sparing or land sharing is more effective (e.g., Green et al. [140]). This can be linked to a dynamic nature conservation approach, as proposed by Bengtsson et al. [141]. They concluded that the existing protected areas and reservations probably cannot maintain the long-term and large-scale ecosystem dynamics on their own, so a large proportion of agricultural area will have to be actively integrated in nature conservation programs. This is supported by conservation research that has appreciated the role of the matrix area between habitat patches of protected species [142].

Polycultures obviously exhibit an increased planned biodiversity (i.e., the species diversity of the crop), which also induces richer associated wild flora and fauna [143]. An additional positive effect on the biodiversity of an agricultural ecosystem could be expected from potentially lower (or less harmful) pesticide application due to better weed suppression [144,145]. Since the addition or loss of species has major effects if the number of species is low [146], any addition to the currently very few crop species in agricultural ecosystems should have significant positive effects on the biodiversity. The design of crop rotations determines the spatial distribution of the fields with different crops across 
a landscape. Field margins and the integration of crop neighbors that clearly differ from each other in their vegetation architecture and cultivation period are important to biodiversity [105].

Growing a perennial crop for up to five years implies an extended ecosystem development beyond the colonization of bare soils, as is typical for annual crops, and allows the development of more ecological complexity, as is typical for the maturing of ecosystems in general, e.g., in forests, which need several decades for succession processes [147]. However, for microorganism communities in compost [148] or soils [149] and for pelagic ecosystems [150], succession is defined over a duration of weeks to months. Therefore, an arable field with perennial plants should also exhibit the ecosystem characteristics of early or mid-stage secondary succession [151]. This supports the reported contribution of perennial crops to a more sustainable agricultural system $[94,114,152]$. Perennial crops contribute to a mixture of population communities with different "ecological ages", which was proposed by Odum [147] for nature conservation in landscape planning [153]. A strategic placement of perennial plants in agricultural landscapes, either on-field or adjacent, likely provides greater benefits than their spatial extent suggests [11,122].

\section{Conclusions}

The analysis of agricultural ES on the basis of crop rotations was suitable for the assessment of long-term effects that are not visible at the single-crop level. The ES concept proved applicable for the comprehensive assessment of agroecosystems, and for highlighting trade-offs between services. However, the ES concept needs to be further developed in order to integrate agricultural inputs and the resulting negative externalities of farming practices. These include the mitigation or compensation of soil losses, greenhouse gas emissions, energy consumption, pesticide resistance, biodiversity losses, and the contamination of soil or water bodies, among other practices.

Based on the ES evaluation, perennial polycultures as an agroecological strategy in cropping system design have the potential to contribute to the sustainable intensification of agricultural systems. The integration of perennial polycultures as a main component of crop rotation effectively provides diverse ES and opportunities for nature conservation. This calls for an adoption strategy to increase the cultivation of perennial polycultures and transition to more sustainable agricultural systems. To overcome the economic constraints for growing such crops, new incentives must be developed.

Acknowledgments: This work was financially supported by the Deutsche Bundesstiftung Umwelt (DBU) and Peter Weißhuhn is thankful for participating in their doctoral scholarship program. The German Federal Ministry of Education and Research provided funding through the FACCE-ERA-NET+ project Climate-CAFE (Grant PTJ-031A544). The publication of this article was funded by the Open Access Fund of the Leibniz Association.

Author Contributions: Peter Weißhuhn and Hubert Wiggering conceived the review. Peter Weißhuhn performed the literature search, the basic analysis, and manuscript drafting. Moritz Reckling and Ulrich Stachow contributed to the analysis and Moritz Reckling, Ulrich Stachow, and Hubert Wiggering revised several versions of the manuscript.

Conflicts of Interest: The authors declare no conflict of interest.

\section{References}

1. Dale, V.H.; Polasky, S. Measures of the effects of agricultural practices on ecosystem services. Ecol. Econ. 2007, 64, 286-296. [CrossRef]

2. Wezel, A.; Bellon, S.; Doré, T.; Francis, C.; Vallod, D.; David, C. Agroecology as a science, a movement and a practice. A review. Agron. Sustain. Dev. 2009, 29, 503-515. [CrossRef]

3. Wezel, A.; Casagrande, M.; Celette, F.; Vian, J.-F.; Ferrer, A.; Peigné, J. Agroecological practices for sustainable agriculture. A review. Agron. Sustain. Dev. 2014, 34, 1-20. [CrossRef]

4. Food and Agriculture Organization of the United Nations (FAO). Save and Grow: A Policymakers's Guide to the Sustainable Intensification of Smallholder Crop Production; Food and Agriculture Organization of the United Nations: Rome, Italy, 2011. 
5. Wolters, V.; Isselstein, J.; Stützel, H.; Ordon, F.; von Haaren, C.; Schlecht, E.; Wesseler, J.; Birner, R.; von Lützow, M.; Brüggemann, N.; et al. Nachhaltige ressourceneffiziente Erhöhung der Flächenproduktivität: Zukunftsoptionen der deutschen Agrarökosystemforschung Grundsatzpapier der DFG Senatskommission für Agrarökosystemforschung. J. Kult. 2014, 66, 225-236. (In German)

6. Firbank, L.G.; Elliott, J.; Drake, B.; Cao, Y.; Gooday, R. Evidence of sustainable intensification among British farms. Agric. Ecosyst. Environ. 2013, 173, 58-65. [CrossRef]

7. Godfray, H.C.J. The debate over sustainable intensification. Food Secur. 2015, 7, 199-208. [CrossRef]

8. Tscharntke, T.; Clough, Y.; Wanger, T.C.; Jackson, L.; Motzke, I.; Perfecto, I.; Vandermeer, J.; Whitbread, A. Global food security, biodiversity conservation and the future of agricultural intensification. Biol. Conserv. 2012, 151, 53-59. [CrossRef]

9. Tittonell, P. Ecological intensification of agriculture-Sustainable by nature. Curr. Opin. Environ. Sustain. 2014, 8, 53-61. [CrossRef]

10. Glover, J.D.; Culman, S.W.; DuPont, S.T.; Broussard, W.; Young, L.; Mangan, M.E.; Mai, J.G.; Crews, T.E.; DeHaan, L.R.; Buckley, D.H.; et al. Harvested perennial grasslands provide ecological benchmarks for agricultural sustainability. Agric. Ecosyst. Environ. 2010, 137, 3-12. [CrossRef]

11. Asbjornsen, H.; Hernandez-Santana, V.; Liebman, M.; Bayala, J.; Chen, J.; Helmers, M.; Ong, C.K.; Schulte, L.A. Targeting perennial vegetation in agricultural landscapes for enhancing ecosystem services. Renew. Agric. Food Syst. 2014, 29, 101-125. [CrossRef]

12. Franzluebbers, A.J. Farming strategies to fuel bioenergy demands and facilitate essential soil services. Geoderma 2015, 259-260, 251-258. [CrossRef]

13. Mast, B.; Lemmer, A.; Oechsner, H.; Reinhardt-Hanisch, A.; Claupein, W.; Graeff-Hönninger, S. Methane yield potential of novel perennial biogas crops influenced by harvest date. Ind. Crops Prod. 2014, 58, 194-203. [CrossRef]

14. Reganold, J.P. Perennial grain systems: A sustainable response to future food security challenges. In Proceedings of the FAO Expert Workshop, Perennial Crops for Food Security, Rome, Italy, 28-30 August 2013; Batello, C., Wade, L., Cox, S., Pogna, N., Bozzini, A., Choptiany, J., Eds.; FAO: Rome, Italy, 2013; pp. 256-265.

15. Zhang, Y.; Jiang, L.; Li, Y.; Tian, C.; Zhang, W.; Li, J.; Xiao, Z. Perennial grain crops: A new option for the future food and ecoagricultural environment. Adv. Mater. Res. 2012, 361-363, 1463-1466. [CrossRef]

16. Igbozurike, U.M. Polyculture and monoculture: Contrast and analysis. GeoJournal 1978, 2, $443-449$. [CrossRef]

17. Sheaffer, C.C.; Moncada, K.M. Introduction to Agronomy: Food, Crops, and Environment, 2nd ed.; Cengage Learning: Delmar, NY, USA, 2012.

18. Burkhard, B.; de Groot, R.; Costanza, R.; Seppelt, R.; Jørgensen, S.E.; Potschin, M. Solutions for sustaining natural capital and ecosystem services. Ecol. Indic. 2012, 21, 1-6. [CrossRef]

19. Wiggering, H.; Weißhuhn, P.; Burkhard, B. Agrosystem services: An additional terminology to better understand ecosystem services delivered by agriculture. Landsc. Online 2016, 49, 1-15. [CrossRef]

20. Harrison, P.A.; Vandewalle, M.; Sykes, M.T.; Berry, P.M.; Bugter, R.; de Bello, F.; Feld, C.K.; Grandin, U.; Harrington, R.; Haslett, J.R.; et al. Identifying and prioritising services in European terrestrial and freshwater ecosystems. Biodivers. Conserv. 2010, 19, 2791-2821. [CrossRef]

21. Power, A.G. Ecosystem services and agriculture: Tradeoffs and synergies. Philos. Trans. R. Soc. B 2010, 365, 2959-2971. [CrossRef] [PubMed]

22. Tscharntke, T.; Klein, A.M.; Kruess, A.; Steffan-Dewenter, I.; Thies, C. Landscape perspectives on agricultural intensification and biodiversity-Ecosystem service management. Ecol. Lett. 2005, 8, 857-874. [CrossRef]

23. Rusch, A.; Bommarco, R.; Jonsson, M.; Smith, H.G.; Ekbom, B. Flow and stability of natural pest control services depend on complexity and crop rotation at the landscape scale. J. Appl. Ecol. 2013, 50, 345-354. [CrossRef]

24. Klein, A.M.; Vaissiere, B.E.; Cane, J.H.; Steffan-Dewenter, I.; Cunningham, S.A.; Kremen, C.; Tscharntke, T. Importance of pollinators in changing landscapes for world crops. Proc. R. Soc. B Biol. Sci. 2007, 274, 303-313. [CrossRef] [PubMed] 
25. Kremen, C.; Williams, N.M.; Aizen, M.A.; Gemmill-Herren, B.; LeBuhn, G.; Minckley, R.; Packer, L.; Potts, S.G.; Roulston, T.A.; Steffan-Dewenter, I.; et al. Pollination and other ecosystem services produced by mobile organisms: A conceptual framework for the effects of land-use change. Ecol. Lett. 2007, 10, 299-314. [CrossRef] [PubMed]

26. Rost, S.; Gerten, D.; Hoff, H.; Lucht, W.; Falkenmark, M.; Rockström, J. Global potential to increase crop production through water management in rainfed agriculture. Environ. Res. Lett. 2009, 4, 4. [CrossRef]

27. Rockström, J.; Falkenmark, M.; Karlberg, L.; Hoff, H.; Rost, S.; Gerten, D. Future water availability for global food production: The potential of green water for increasing resilience to global change. Water Resour. Res. 2009, 45. [CrossRef]

28. Zhang, W.; Ricketts, T.H.; Kremen, C.; Carney, K.; Swinton, S.M. Ecosystem services and dis-services to agriculture. Ecol. Econ. 2007, 64, 253-260. [CrossRef]

29. Dury, J.; Schaller, N.; Garcia, F.; Reynaud, A.; Bergez, J.E. Models to support cropping plan and crop rotation decisions. A review. Agron. Sustain. Dev. 2011, 32, 567-580. [CrossRef]

30. Reckling, M.; Hecker, J.-M.; Bergkvist, G.; Watson, C.A.; Zander, P.; Schläfke, N.; Stoddard, F.L.; Eory, V.; Topp, C.F.E.; Maire, J.; et al. A cropping system assessment framework-Evaluating effects of introducing legumes into crop rotations. Eur. J. Agron. 2016, 76, 186-197. [CrossRef]

31. Dogliotti, S.; Rossing, W.A.H.; van Ittersum, M.K. Rotat, a tool for systematically generating crop rotations. Eur. J. Agron. 2003, 19, 239-250. [CrossRef]

32. Castellazzi, M.S.; Wood, G.A.; Burgess, P.J.; Morris, J.; Conrad, K.F.; Perry, J.N. A systematic representation of crop rotations. Agric. Syst. 2008, 97, 26-33. [CrossRef]

33. Vereijken, P. A methodical way of prototyping integrated and ecological arable farming systems (i/eafs) in interaction with pilot farms. Eur. J. Agron. 1997, 7, 235-250. [CrossRef]

34. Cattani, D.J. Perennial polycultures: How do we assemble a truly sustainable agricultural system? In Proceedings of the FAO Expert Workshop, Perennial Crops for Food Security, Rome, Italy, 28-30 August 2013; Batello, C., Wade, L., Cox, S., Pogna, N., Bozzini, A., Choptiany, J., Eds.; FAO: Rome, Italy, 2013; pp. 324-338.

35. Oates, L.G.; Duncan, D.S.; Gelfand, I.; Millar, N.; Robertson, G.P.; Jackson, R.D. Nitrous oxide emissions during establishment of eight alternative cellulosic bioenergy cropping systems in the north central United States. GCB Bioenergy 2016, 8, 539-549. [CrossRef]

36. Carlsson, G.; Mårtensson, L.-M.; Prade, T.; Svensson, S.-E.; Jensen, E.S. Perennial species mixtures for multifunctional production of biomass on marginal land. Glob. Chang. Biol. Bioenergy 2017, 9, 191-201. [CrossRef]

37. Suter, M.; Finn, J.A.; Connolly, J.; Loges, R.; Lüscher, A. Gain in nitrogen yield from grass-legume mixtures is robust over a wide range of legume proportions and environmental conditions. Procedia Environ. Sci. 2015, 29, 187-188. [CrossRef]

38. Lüscher, A.; Mueller-Harvey, I.; Soussana, J.F.; Rees, R.M.; Peyraud, J.L. Potential of legume-based grassland-livestock systems in Europe: A review. Grass Forage Sci. 2014, 69, 206-228. [CrossRef] [PubMed]

39. Vollrath, B.; Werner, A.; Marzini, K.; Degenbeck, M. Wildpflanzenmischungen als Biogassubstrat; ALB Bayern e.V.: Freising, Germany, 2013. (In German)

40. Von Cossel, M.; Lewandowski, I. Perennial wild plant mixtures for biomass production: Impact of species composition dynamics on yield performance over a five-year cultivation period in southwest Germany. Eur. J. Agron. 2016, 79, 74-89. [CrossRef]

41. Stein, C.; Hallett, L.M.; Harpole, W.S.; Suding, K.N. Evaluating ecosystem services provided by non-native species: An experimental test in California grasslands. PLoS ONE 2014, 9, e75396. [CrossRef] [PubMed]

42. Häyhä, T.; Franzese, P.P. Ecosystem services assessment: A review under an ecological-economic and systems perspective. Ecol. Model. 2014, 289, 124-132. [CrossRef]

43. Schirpke, U.; Scolozzi, R.; De Marco, C.; Tappeiner, U. Mapping beneficiaries of ecosystem services flows from natura 2000 sites. Ecosyst. Serv. 2014, 9, 170-179. [CrossRef]

44. Kollas, C.; Kersebaum, K.C.; Nendel, C.; Manevski, K.; Müller, C.; Palosuo, T.; Armas-Herrera, C.M.; Beaudoin, N.; Bindi, M.; Charfeddine, M. Crop rotation modelling-A European model intercomparison. Eur. J. Agron. 2015, 70, 98-111. [CrossRef]

45. Lin, B.B. Resilience in agriculture through crop diversification: Adaptive management for environmental change. BioScience 2011, 61, 183-193. [CrossRef] 
46. Mudgal, S.; Lavelle, P.; Cachia, F.; Somogyi, D.; Majewski, E.; Fontaine, L.; Bechini, L.; Debaeke, P. Environmental Impacts of Different Crop Rotations in the European Union; European Commission: Brussels, Belgium, 2010.

47. Reckling, M.; Bergkvist, G.; Watson, C.A.; Stoddard, F.L.; Zander, P.M.; Walker, R.L.; Pristeri, A.; Toncea, I.; Bachinger, J. Trade-offs between economic and environmental impacts of introducing legumes into cropping systems. Front. Plant Sci. 2016, 7, 669. [CrossRef] [PubMed]

48. Freyer, B. Fruchtfolgen, 1st ed.; Eugen Ulmer Verlag: Stuttgart, Germany, 2003; p. 230. (In German)

49. Oerke, E.C.; Dehne, H.W. Safeguarding production-Losses in major crops and the role of crop protection. Crop Prot. 2004, 23, 275-285. [CrossRef]

50. Nicholson, G.M. Fighting the global pest problem: Preface to the special toxicon issue on insecticidal toxins and their potential for insect pest control. Toxicon 2007, 49, 413-422. [CrossRef] [PubMed]

51. Whalon, M.E. Introduction. In Global Pesticide Resistance in Arthropods; Whalon, M.E., Mota-Sanchez, D., Hollingworth, R.M., Eds.; CAB International: Oxfordshire, UK; Cambridge, MA, USA, 2008; pp. 1-4.

52. Liebman, M.; Dyck, E. Crop rotation and intercropping strategies for weed management. Ecol. Appl. 1993, 3, 92-122. [CrossRef] [PubMed]

53. De Groot, R.; Fisher, B.; Christie, M.; Aronson, J.; Braat, L.; Gowdy, J.; Haines-Young, R.; Maltby, E.; Neuville, A.; Polasky, S.; et al. Chapter 1-Integrating the ecological and economic dimensions in biodiversity and ecosystem service valuation. In The Economics of Ecosystems and Biodiversity: The Ecological and Economic Foundations; Kumar, P., Ed.; Earthscan: London, UK; Washington, DC, USA, 2010.

54. MEA. Ecosystems and Human Well-Being: Current State and Trends; Island Press: Washington, DC, USA; Covelo, CA, USA; London, UK, 2005; Volume 1.

55. Boyd, J.; Banzhaf, S. What are ecosystem services? The need for standardized environmental accounting units. Ecol. Econ. 2007, 63, 616-626. [CrossRef]

56. Haines-Young, R.; Potschin, M. Cices Version 4: Response to Consultation; Centre for Environmental Management, University of Nottingham: Nottingham, UK, 2012.

57. Braun, M.; Schmid, H.; Grundler, T.; Hülsbergen, K.J. Root-and-shoot growth and yield of different grass-Clover mixtures. Plant Biosyst. 2010, 144, 414-419. [CrossRef]

58. Biewer, S.; Fricke, T.; Wachendorf, M. Determination of dry matter yield from legume-grass swards by field spectroscopy. Crop Sci. 2009, 49, 1927-1936. [CrossRef]

59. McElroy, M.; Papadopoulos, Y.A.; Glover, K.E.; Dong, Z.; Fillmore, S.A.E.; Johnston, M.O. Interactions between cultivars of legumes species (Trifolium pratense L., Medicago sativa L.) and grasses (Phleum pratense L., Lolium perenne L.) under different nitrogen levels. Can. J. Plant Sci. 2016. [CrossRef]

60. Sleugh, B.; Moore, K.J.; George, J.R.; Brummer, E.C. Binary legume-grass mixtures improve forage yield, quality, and seasonal distribution. Agron. J. 2000, 92, 24-29. [CrossRef]

61. Braun, M.; Schmid, H.; Grundler, T. Vergleich verschiedener klee-gras-mischungen anhand der wurzel-und sprossleistung. In Angewandte Forschung und Beratung für den Ökologischen Landbau in Bayern; Wiesinger, K., Cais, K., Eds.; Bayerischen Landesanstalt für Landwirtschaft (LfL): Freising-Weihenstephan, Germany, 2009; pp. 35-42. (In German)

62. Rochon, J.J.; Doyle, C.J.; Greef, J.M.; Hopkins, A.; Molle, G.; Sitzia, M.; Scholefield, D.; Smith, C.J. Grazing legumes in Europe: A review of their status, management, benefits, research needs and future prospects. Grass Forage Sci. 2004, 59, 197-214. [CrossRef]

63. FNR. Anbau Nachwachsender Rohstoffe 2013 auf 2,4 Millionen Hektar; Fachagentur Nachwachsende Rohstoffe e.V.: OT Gülzow, Germany, 2013. (In German)

64. Vollrath, B.; Werner, A. Wildpflanzen rentabel vergären. Dlz Agrarmagazin 2012, 12, 42-46. Available online: https:/ / www.agrarheute.com/dlz/heftarchiv-dlz (accessed on 6 December 2017). (In German)

65. Vollrath, B.; Werner, A.; Degenbeck, M.; Marzini, K. Energetische Verwertung von Kräuterreichen Ansaaten in der Agrarlandschaft-Eine Ökologische und Wirtschaftliche Alternative bei der Biogasproduktion (Phase II); Bayerische Landesanstalt für Weinbau und Gartenbau (LWG): Veitshöchheim, Germany, 2016. (In German)

66. Wüstemann, H.; Albrecht, K.; Matzdorf, B.; Schuler, J. Theoretische grundlagen von politiken zur förderung der multifunktionalität. In Multifunktionalität_Von der Wohlfahrtsökonomie zu Neuen Ufern; Wüstemann, H., Mann, S., Müller, K., Eds.; Oekom: München, Germany, 2008; pp. 58-84. (In German) 
67. Costanza, R.; d'Arge, R.; de Groot, R.; Farber, S.; Grasso, M.; Hannon, B.; Limburg, K.; Naeem, S.; O’Neill, R.V.; Paruelo, J.; et al. The value of the world's ecosystem services and natural capital. Nature 1997, 387, 253-260. [CrossRef]

68. De Groot, R.S.; Alkemade, R.; Braat, L.; Hein, L.; Willemen, L. Challenges in integrating the concept of ecosystem services and values in landscape planning, management and decision making. Ecol. Complex. 2010, 7, 260-272. [CrossRef]

69. Björklund, J.; Limburg, K.E.; Rydberg, T. Impact of production intensity on the ability of the agricultural landscape to generate ecosystem services: An example from Sweden. Ecol. Econ. 1999, 29, 269-291. [CrossRef]

70. Niggli, U.; Schmid, O.; Stolze, M.; Sanders, J.; Schader, C.; Fliessbach, A.; Mäder, P.; Klocke, P.; Wyss, G.; Balmer, O. Gesellschaftliche Leistungen der Biologischen Landwirtschaft; Forschungsinstitut für Biologischen Landbau FiBL: Frick, Schweiz, 2009. (In German)

71. Sandhu, H.S.; Wratten, S.D.; Cullen, R. Organic agriculture and ecosystem services. Environ. Sci. Policy 2010, 13, 1-7. [CrossRef]

72. Alam, M.; Olivier, A.; Paquette, A.; Dupras, J.; Revéret, J.-P.; Messier, C. A general framework for the quantification and valuation of ecosystem services of tree-based intercropping systems. Agrofor. Syst. 2014, 88, 679-691. [CrossRef]

73. Van der Biest, K.; D’Hondt, R.; Jacobs, S.; Landuyt, D.; Staes, J.; Goethals, P.; Meire, P. Ebi: An index for delivery of ecosystem service bundles. Ecol. Indic. 2014, 37, 252-265. [CrossRef]

74. Raudsepp-Hearne, C.; Peterson, G.D.; Bennett, E.M. Ecosystem service bundles for analyzing tradeoffs in diverse landscapes. Proc. Natl. Acad. Sci. USA 2010, 107, 5242-5247. [CrossRef] [PubMed]

75. Frank, S.; Fürst, C.; Koschke, L.; Witt, A.; Makeschin, F. Assessment of landscape aesthetics-validation of a landscape metrics-based assessment by visual estimation of the scenic beauty. Ecol. Indic. 2013, 32, 222-231. [CrossRef]

76. Franzluebbers, A.J.; Sawchik, J.; Taboada, M.A. Agronomic and environmental impacts of pasture-crop rotations in temperate north and south America. Agric. Ecosyst. Environ. 2014, 190, 18-26. [CrossRef]

77. Ebertseder, T.; Engels, C.; Heyn, J.; Reinhold, J.; Brock, C.; Fürstenfeld, F.; Hülsbergen, K.J.; Isermann, K.; Kolbe, H.; Leithold, G.; et al. Humusbilanzierung. Eine Methode zur Analyse und Bewertung der Humusversorgung von Ackerland; Verband Deutscher Landwirtschaftlicher Untersuchungs-und Forschungsanstalten (VDLUFA): Speyer, Germany, 2014; p. 21. (In German)

78. Bergkvist, G.; Båth, B. Nitrogen fertiliser dose influence the effect of two year rotational leys with grass or clover/grass on other crops in the rotation. Asp. Appl. Biol. 2015, 128, 133-139.

79. Loges, R. Leguminosen im futterbau: Aktuelle und zukünftige bedeutung sowie forschungsbedarf. In 57. Jahrestagung der Arbeitsgemeinschaft für Grünland und Futterbau (AGGF); Institut für Pflanzenbau und Pflanzenzüchtung der Bayerischen Landesanstalt für Landwirtschaft: Triesdorf, Germany, 2013; pp. 9-20. (In German)

80. Sturludóttir, E.; Brophy, C.; Bélanger, G.; Gustavsson, A.M.; Jørgensen, M.; Lunnan, T.; Helgadóttir, Á. Benefits of mixing grasses and legumes for herbage yield and nutritive value in northern Europe and Canada. Grass Forage Sci. 2014, 69, 229-240. [CrossRef]

81. Finney, D.M.; White, C.M.; Kaye, J.P. Biomass production and carbon/nitrogen ratio influence ecosystem services from cover crop mixtures. Agron. J. 2016, 108, 39-52. [CrossRef]

82. Schmid, H.; Braun, M.; Hülsbergen, K.J. Treibhausgasbilanzen und ökologische Nachhaltigkeit der Pflanzenproduktion-Ergebnisse aus dem Netzwerk der Pilotbetriebe. In Klimawirkungen und Nachhaltigkeit Ökologischer und Konventioneller Betriebssysteme-Untersuchungen in einem Netzwerk von Pilotbetrieben; Bundesanstalt für Landwirtschaft und Ernährung (BLE): Weihenstephan, Germany, 2012; Volume 3, pp. 204-233. (In German)

83. LfL. Luzerne. Anbau-Konservierung-Verfütterung; Institut für Tierernährung und Futterwirtschaft der Bayerischen Landesanstalt für Landwirtschaft: Freising-Weihenstephan, Germany, 2013. (In German)

84. LfL. Eiweißfuttermittel in der Rinderfütterung; Institut für Tierernährung und Futterwirtschaft der Bayerischen Landesanstalt für Landwirtschaft: Freising-Weihenstephan, Germany, 2013. (In German)

85. Grunewald, J.; Jäkel, K. Standortangepasste Anbausysteme für Energiepflanzen zur Biogasprodktion; Landesamt für Umwelt, Landwirtschaft und Geologie: Dresden, Germany, 2014; p. 142. Available online: https: / / publikationen.sachsen.de/bdb/artikel/22636 (accessed on 6 December 2017). (In German) 
86. Schläfke, N.; Uckert, G. Ii.1.4 Modellierung der landwirtschaftlichen Landnutzung im Landkreis Görlitz. In Schlussbericht für das BMBF-Forschungsvorhaben Löbestein; Syrbe, R.-U., Steinhäußer, R., Eds.; Leibniz-Institut für Ökologische Raumentwicklung (IÖR): Dresden, Germany, 2014; pp. 60-108. (In German)

87. Zürcher, A.; Stolzenburg, K.; Messner, J.; Wurth, W.; Löffler, C. Was leisten alternative Kulturen im Vergleich zu Energiemais? Landinfo 2013, 5, 45-50. Available online: https:/ / www.landwirtschaft-bw.info/pb/site/ pbs-bw-new/get/documents/MLR.LEL/PB5Documents/lel/Abteilung_1/Landinfo/Landinfo_extern/ 05_13/alternative_Kulturen_Energiemais_Zuercher.pdf (accessed on 6 December 2017). (In German)

88. Hamza, M.A.; Anderson, W.K. Soil compaction in cropping systems: A review of the nature, causes and possible solutions. Soil Tillage Res. 2005, 82, 121-145. [CrossRef]

89. Auerswald, K. Bodeneigenschaften und Bodenerosion; Wirkungswege bei Unterschiedlichen Betrachtungsmaßstäben; Gebrüder Borntraeger Verlag: Berlin/Stuttgart, Germany, 1993; p. 208. (In German)

90. Sreelash, K.; Sekhar, M.; Ruiz, L.; Buis, S.; Bandyopadhyay, S. Improved modeling of ground water recharge in agricultural watersheds using a combination of crop model and remote sensing. J. Indian Inst. Sci. 2013, 93, 189-208.

91. Bastian, O. Ii.1.5 Bewertung der Szenarien aus ökosystemarer Perspektive. In Schlussbericht für das BMBF-Forschungsvorhaben Löbestein; Syrbe, R.-U., Steinhäußer, R., Eds.; Leibniz-Institut für Ökologische Raumentwicklung (IÖR): Dresden, Germany, 2014; pp. 109-132. (In German)

92. Taube, F. Klimawandel und Futterbau. In 53. Jahrestagung der Arbeitsgemeinschaft für Grünland und Futterbau (AGGF); Berendonk, C., Riel, G., Eds.; Landwirtschaftskammer Nordrhein-Westfalen: Kleeve, Germany, 2009; Volume 10, pp. 7-24. (In German)

93. Abalos, D.; Brown, S.E.; Vanderzaag, A.C.; Gordon, R.J.; Dunfield, K.E.; Wagner-Riddle, C. Micrometeorological measurements over 3 years reveal differences in $\mathrm{N}_{2} \mathrm{O}$ emissions between annual and perennial crops. Glob. Chang. Biol. 2016, 22, 1244-1255. [CrossRef] [PubMed]

94. Werling, B.P.; Dickson, T.L.; Isaacs, R.; Gaines, H.; Gratton, C.; Gross, K.L.; Liere, H.; Malmstrom, C.M.; Meehan, T.D.; Ruan, L.; et al. Perennial grasslands enhance biodiversity and multiple ecosystem services in bioenergy landscapes. Proc. Natl. Acad. Sci. USA 2014, 111, 1652-1657. [CrossRef] [PubMed]

95. Andersson, G.K.S.; Ekroos, J.; Stjernman, M.; Rundlöf, M.; Smith, H.G. Effects of farming intensity, crop rotation and landscape heterogeneity on field bean pollination. Agric. Ecosyst. Environ. 2014, 184, 145-148. [CrossRef]

96. Steffan-Dewenter, I.; Westphal, C. The interplay of pollinator diversity, pollination services and landscape change. J. Appl. Ecol. 2008, 45, 737-741. [CrossRef]

97. Lonsdorf, E.; Kremen, C.; Ricketts, T.; Winfree, R.; Williams, N.; Greenleaf, S. Modelling pollination services across agricultural landscapes. Ann. Bot. 2009, 103, 1589-1600. [CrossRef] [PubMed]

98. Morandin, L.A.; Kremen, C. Hedgerow restoration promotes pollinator populations and exports native bees to adjacent fields. Ecol. Appl. 2013, 23, 829-839. [CrossRef] [PubMed]

99. Garibaldi, L.A.; Steffan-Dewenter, I.; Kremen, C.; Morales, J.M.; Bommarco, R.; Cunningham, S.A.; Carvalheiro, L.G.; Chacoff, N.P.; Dudenhoffer, J.H.; Greenleaf, S.S.; et al. Stability of pollination services decreases with isolation from natural areas despite honey bee visits. Ecol. Lett. 2011, 14, 1062-1072. [CrossRef] [PubMed]

100. Lentini, P.E.; Martin, T.G.; Gibbons, P.; Fischer, J.; Cunningham, S.A. Supporting wild pollinators in a temperate agricultural landscape: Maintaining mosaics of natural features and production. Biol. Conserv. 2012, 149, 84-92. [CrossRef]

101. Pywell, R.F.; Meek, W.R.; Hulmes, L.; Hulmes, S.; James, K.L.; Nowakowski, M.; Carvell, C. Management to enhance pollen and nectar resources for bumblebees and butterflies within intensively farmed landscapes. J. Insect Conserv. 2011, 15, 853-864. [CrossRef]

102. Blaauw, B.R.; Isaacs, R. Larger patches of diverse floral resources increase insect pollinator density, diversity, and their pollination of native wildflowers. Basic Appl. Ecol. 2014, 15, 701-711. [CrossRef]

103. Meehan, T.D.; Werling, B.P.; Landis, D.A.; Gratton, C. Pest-suppression potential of midwestern landscapes under contrasting bioenergy scenarios. PLoS ONE 2012, 7, e41728. [CrossRef] [PubMed]

104. Letourneau, D.K.; Bothwell Allen, S.G.; Stireman, J.O.; Lewis, O. Perennial habitat fragments, parasitoid diversity and parasitism in ephemeral crops. J. Appl. Ecol. 2012, 49, 1405-1416. [CrossRef] 
105. Glemnitz, M.; Platen, R.; Saure, C. Auswirkungen des Anbaus von Energiepflanzen auf die Biodiversität: Bewertungsmethodik und Einfluss des Anbauverfahrens; 468; Kuratorium für Technik und Bauwesen in der Landwirtschaft e.V. (KTBL): Darmstadt, Germany, 2008; pp. 136-151. (In German)

106. Kirkegaard, J.; Christen, O.; Krupinsky, J.; Layzell, D. Break crop benefits in temperate wheat production. Field Crops Res. 2008, 107, 185-195. [CrossRef]

107. Seymour, M.; Kirkegaard, J.A.; Peoples, M.B.; White, P.F.; French, R.J. Break-crop benefits to wheat in western australia-Insights from over three decades of research. Crop Pasture Sci. 2012, 63, 1-16. [CrossRef]

108. Diehl, E.; Sereda, E.; Wolters, V.; Birkhofer, K.; Paynter, Q. Effects of predator specialization, host plant and climate on biological control of aphids by natural enemies: A meta-analysis. J. Appl. Ecol. 2013, 50, 262-270. [CrossRef]

109. Håkansson, S. Weeds with diverse life forms in various types of crops. In Weeds and Weed Management on Arable Land: An Ecological Approach; Håkansson, S., Ed.; CABI: Wallingford, Oxfordshire, UK, 2003; pp. $20-55$.

110. Wortman, S.E.; Lindquist, J.L.; Haar, M.J.; Francis, C.A. Increased weed diversity, density and above-ground biomass in long-term organic crop rotations. Renew. Agric. Food Syst. 2010, 25, 281-295. [CrossRef]

111. Grass, I.; Albrecht, J.; Jauker, F.; Diekötter, T.; Warzecha, D.; Wolters, V.; Farwig, N. Much more than bees-Wildflower plantings support highly diverse flower-visitor communities from complex to structurally simple agricultural landscapes. Agric. Ecosyst. Environ. 2016, 225, 45-53. [CrossRef]

112. Ode, Å.; Hagerhall, C.M.; Sang, N. Analysing visual landscape complexity: Theory and application. Landsc. Res. 2010, 35, 111-131. [CrossRef]

113. Junge, X.; Schüpbach, B.; Walter, T.; Schmid, B.; Lindemann-Matthies, P. Aesthetic quality of agricultural landscape elements in different seasonal stages in Switzerland. Landsc. Urban Plan. 2015, 133, 67-77. [CrossRef]

114. Meehan, T.D.; Gratton, C.; Diehl, E.; Hunt, N.D.; Mooney, D.F.; Ventura, S.J.; Barham, B.L.; Jackson, R.D. Ecosystem-service tradeoffs associated with switching from annual to perennial energy crops in riparian zones of the US Midwest. PLoS ONE 2013, 8. [CrossRef] [PubMed]

115. Schößer, B.; Helming, K.; Wiggering, H. Assessing land use change impacts-A comparison of the sensor land use function approach with other frameworks. J. Land Use Sci. 2010, 5, 159-178. [CrossRef]

116. Schomers, S.; Matzdorf, B. Payments for ecosystem services: A review and comparison of developing and industrialized countries. Ecosyst. Serv. 2013, 6, 16-30. [CrossRef]

117. Rapidel, B.; Ripoche, A.; Allinne, C.; Metay, A.; Deheuvels, O.; Lamanda, N.; Blazy, J.-M.; Valdés-Gómez, H.; Gary, C. Analysis of ecosystem services trade-offs to design agroecosystems with perennial crops. Agron. Sustain. Dev. 2015, 35, 1373-1390. [CrossRef]

118. Burkhard, B.; Kroll, F.; Nedkov, S.; Müller, F. Mapping ecosystem service supply, demand and budgets. Ecol. Indic. 2012, 21, 17-29. [CrossRef]

119. Burkhard, B.; Kandziora, M.; Hou, Y.; Müller, F. Ecosystem service potentials, flows and demands-Concepts for spatial localisation, indication and quantification. Landsc. Online 2014, 34, 1-32. [CrossRef]

120. Polasky, S.; Tallis, H.; Reyers, B. Setting the bar: Standards for ecosystem services. Proc. Natl. Acad. Sci. USA 2015, 112, 7356-7361. [CrossRef] [PubMed]

121. Albert, C.; Bonn, A.; Burkhard, B.; Daube, S.; Dietrich, K.; Engels, B.; Frommer, J.; Götzl, M.; Grêt-Regamey, A.; Job-Hoben, B.; et al. Towards a national set of ecosystem service indicators: Insights from germany. Ecol. Indic. 2016, 61, 38-48. [CrossRef]

122. Schulte, L.A.; Liebman, M.; Asbjornsen, H.; Crow, T.R. Agroecosystem restoration through strategic integration of perennials. J. Soil Water Conserv. 2006, 61, 164a-169a.

123. Tidåker, P.; Sundberg, C.; Öborn, I.; Kätterer, T.; Bergkvist, G. Rotational grass/clover for biogas integrated with grain production-A life cycle perspective. Agric. Syst. 2014, 129, 133-141. [CrossRef]

124. Huyghe, C.; Vliegher, A.D.; Golinski, P. European Grasslands Overview: Temperate Region; CABI: Wallingford, Oxfordshire, UK, 2014; pp. 29-40.

125. Picasso, V.D.; Brummer, E.C.; Liebman, M.; Dixon, P.M.; Wilsey, B.J. Diverse perennial crop mixtures sustain higher productivity over time based on ecological complementarity. Renew. Agric. Food Syst. 2011, 26, 317-327. [CrossRef]

126. Malézieux, E.; Crozat, Y.; Dupraz, C.; Laurans, M.; Makowski, D.; Ozier-Lafontaine, H.; Rapidel, B.; Tourdonnet, S.; Valantin-Morison, M. Mixing plant species in cropping systems: Concepts, tools and models: A review. Agron. Sustain. Dev. 2009, 29, 43-62. [CrossRef] 
127. Pelzer, E.; Bazot, M.; Makowski, D.; Corre-Hellou, G.; Naudin, C.; Al Rifai, M.; Baranger, E.; Bedoussac, L.; Biarnes, V.; Boucheny, P.; et al. Pea-wheat intercrops in low-input conditions combine high economic performances and low environmental impacts. Eur. J. Agron. 2012, 40, 39-53. [CrossRef]

128. Bedoussac, L.; Journet, E.P.; Hauggaard-Nielsen, H.; Naudin, C.; Corre-Hellou, G.; Jensen, E.; Prieur, L.; Justes, E. Ecological principles underlying the increase of productivity achieved by cereal-grain legume intercrops in organic farming. A review. Agron. Sustain. Dev. 2015, 35, 911-935. [CrossRef]

129. Hauggaard-Nielsen, H.; Gooding, M.; Ambus, P.; Corre-Hellou, G.; Crozat, Y.; Dahlmann, C.; Dibet, A.; von Fragstein, P.; Pristeri, A.; Monti, M.; et al. Pea-barley intercropping and short-term subsequent crop effects across european organic cropping conditions. Nutr. Cycl. Agroecosyst. 2009, 85, 141-155. [CrossRef]

130. Hauggaard-Nielsen, H.; Jørnsgaard, B.; Kinane, J.; Jensen, E.S. Grain legume-cereal intercropping: The practical application of diversity, competition and facilitation in arable and organic cropping systems. Renew. Agric. Food Syst. 2008, 23, 3-12. [CrossRef]

131. Raseduzzaman, M.; Jensen, E.S. Does intercropping enhance yield stability in arable crop production? A meta-analysis. Eur. J. Agron. 2017, 91, 25-33. [CrossRef]

132. Frison, E.A.; Cherfas, J.; Hodgkin, T. Agricultural biodiversity is essential for a sustainable improvement in food and nutrition security. Sustainability 2011, 3, 238-253. [CrossRef]

133. Döring, T.F. Re-thinking research on intercropping systems. In 59. Jahrestagung der Gesellschaft für Pflanzenbauwissenschaften; Kage, H., Sieling, K., Francke-Weltmann, L., Eds.; Gesellschaft für Pflanzenbauwissenschaften e.V.: Gießen, Germany, 2016; Volume 28, pp. 32-33. (In German)

134. Vandermeer, J.; Lawrence, D.; Symstad, A.; Hobbie, S. Chapter 19-Effect of biodiversity on ecosystem functioning in managed ecosystems. In Biodiversity and Ecosystem Functioning: Synthesis and Perspectives; Loreau, M., Naeem, S., Inchausti, P., Eds.; Oxford University Press: Oxford, UK; New York, NY, USA, 2002; pp. 221-233.

135. Sanford, G.R.; Oates, L.G.; Jasrotia, P.; Thelen, K.D.; Robertson, G.P.; Jackson, R.D. Comparative productivity of alternative cellulosic bioenergy cropping systems in the north central USA. Agric. Ecosyst. Environ. 2016, 216, 344-355. [CrossRef]

136. Connor, D.J.; Loomis, R.S.; Cassman, K.G. Crop Ecology: Productivity and Management in Agricultural Systems, 2nd ed.; Cambridge University Press: Cambridge, UK, 2011.

137. Kantar, M.B.; Tyl, C.E.; Dorn, K.M.; Zhang, X.; Jungers, J.M.; Kaser, J.M.; Schendel, R.R.; Eckberg, J.O.; Runck, B.C.; Bunzel, M.; et al. Perennial grain and oilseed crops. Annu. Rev. Plant Biol. 2016, 67, 703-729. [CrossRef] [PubMed]

138. Kane, D.A.; Rogé, P.; Snapp, S.S. A systematic review of perennial staple crops literature using topic modeling and bibliometric analysis. PLoS ONE 2016, 11, e0155788. [CrossRef] [PubMed]

139. Bozzini, A. Present situation concerning the introduction of perennial habit into most important annual crops. In Proceedings of the FAO Expert Workshop, Perennial Crops for Food Security, Rome, Italy, 28-30 August 2013; Batello, C., Wade, L., Cox, S., Pogna, N., Bozzini, A., Choptiany, J., Eds.; FAO: Rome, Italy, 2013; pp. 376-379.

140. Green, R.E.; Cornell, S.J.; Scharlemann, J.P.; Balmford, A. Farming and the fate of wild nature. Science 2005, 307, 550-555. [CrossRef] [PubMed]

141. Bengtsson, J.; Angelstam, P.; Elmqvist, T.; Emanuelsson, U.; Folke, C.; Ihse, M.; Moberg, F.; Nystrom, M. Reserves, resilience and dynamic landscapes. Ambio 2003, 32, 389-396. [CrossRef] [PubMed]

142. Perfecto, I.; Vandermeer, J. Biodiversity conservation in tropical agroecosystems: A new conservation paradigm. Ann. N. Y. Acad. Sci. 2008, 1134, 173-200. [CrossRef] [PubMed]

143. Altieri, M.A. The ecological role of biodiversity in agroecosystems. Agric. Ecosyst. Environ. 1999, 74, 19-31. [CrossRef]

144. Poggio, S.L. Structure of weed communities occurring in monoculture and intercropping of field pea and barley. Agric. Ecosyst. Environ. 2005, 109, 48-58. [CrossRef]

145. Suter, M.; Hofer, D.; Lüscher, A. Weed suppression enhanced by increasing functional trait dispersion and resource capture in forage ley mixtures. Agric. Ecosyst. Environ. 2017, 240, 329-339. [CrossRef]

146. WBGU. Welt im Wandel: Erhaltung und Nachhaltige Nutzung der Biosphäre. Jahresgutachten 1999; 3-540-67106-4; Wissenschaftlicher Beirat der Bundesregierung Globale, Umweltveränderungen: Berlin/Heidelberg, Germany, 2000. (In German)

147. Odum, E.P. The strategy of ecosystem development. Science 1969, 164, 262-270. [CrossRef] [PubMed] 
148. Ryckeboer, J.; Mergaert, J.; Coosemans, J.; Deprins, K.; Swings, J. Microbiological aspects of biowaste during composting in a monitored compost bin. J. Appl. Microbiol. 2003, 94, 127-137. [CrossRef] [PubMed]

149. Eisenhauer, N.; Reich, P.B.; Scheu, S. Increasing plant diversity effects on productivity with time due to delayed soil biota effects on plants. Basic Appl. Ecol. 2012, 13, 571-578. [CrossRef]

150. Sommer, U. Pelagische Nahrungsketten und Nahrungsnetze. In Planktologie; Springer: Berlin/Heidelberg, Germany, 1994; pp. 187-222. (In German)

151. Crews, T.E.; Blesh, J.; Culman, S.W.; Hayes, R.C.; Jensen, E.S.; Mack, M.C.; Peoples, M.B.; Schipanski, M.E. Going where no grains have gone before: From early to mid-succession. Agric. Ecosyst. Environ. 2016, 223, 223-238. [CrossRef]

152. Zhang, Y.; Li, Y.; Jiang, L.; Tian, C.; Li, J.; Xiao, Z. Potential of Perennial Crop on Environmental Sustainability of Agriculture. Procedia Environ. Sci. 2011, 10, 1141-1147. [CrossRef]

153. Voigt, A.C.E. Theorien Synökologischer Einheiten-Ein Beitrag zur Erklärung der Uneindeutigkeit des Ökosystembegriffs; Monographie, Technische Universität München: München, Germany, 2008. (In German)

(C) 2017 by the authors. Licensee MDPI, Basel, Switzerland. This article is an open access article distributed under the terms and conditions of the Creative Commons Attribution (CC BY) license (http:/ / creativecommons.org/licenses/by/4.0/). 